\title{
Post-fire fuel succession in a rare California, USA, closed-cone conifer
}

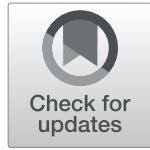

\author{
Bret A. McNamara, Jeffrey M. Kane* (iD and David F. Greene
}

\begin{abstract}
Background: Increasing frequency and size of wildfires over the past few decades have prompted concerns that populations of obligate seeding species may be vulnerable to repeat, short-interval fires that occur prior to these species reaching maturity. The susceptibility of populations to this risk is partially dependent on the amount and characteristics of fuel loading over time and their influence on fire behavior and effects. This study characterized fuel dynamics and modeled fire behavior across a time-since-fire chronosequence in stands of the rare, serotinous conifer, Baker cypress (Hesperocyparis bakeri [Jeps.] Bartel), ranging in age between 3 and 147 years post fire.

Results: Litter and fine woody fuel loading (1- to 100-hour) were highest in the 10-year-old and 147-yearold stands, while coarse fuel loading (1000-hour) peaked in the 10-year-old stand and subsequently decreased with time since fire. Duff loading consistently increased with time since fire. Cone production had not occurred in the first $10 \mathrm{yr}$ of stand development. Foliar moisture content in Baker cypress was inversely correlated with stand age, and older foliage had lower moisture content than younger foliage. Modeled surface fire behavior was highest in the 10-year-old and 107-year-old stands in accordance with higher litter, fine woody fuel, or shrub fuel accumulation. While foliar moisture content was higher in younger stands and influenced the critical fireline intensity, we did not observe changes in fire type.

Conclusions: Fine-fuel loading in Baker cypress stands followed a U-shaped pattern over time (first decreasing, then stable, then increasing), consistent with findings in other forests with stand-replacing fire regimes. Our results indicated that early-successional stages of Baker cypress forests have sufficient fuels to allow for the spread of wildfire and 10-year-old stands could burn with substantive fire behavior prior to cone production. Whenever possible, we recommend suppressing wildfire in stands less than $20 \mathrm{yr}$ old to avoid substantial decreases or local extirpation of these rare Baker cypress populations. Our results highlight the importance of knowing the cone production patterns, fuel dynamics, and corresponding fire behavior over the development of obligate-seeder species to assess the risk of population loss due to short-interval fires.
\end{abstract}

Keywords: Baker cypress, fuel chronosequence, fuel loading, fuel succession, Hesperocyparis bakeri, immaturity risk, senescence risk, serotiny

\footnotetext{
* Correspondence: jkane@humboldt.edu

Department of Forestry and Wildland Resources, Humboldt State University,

One Harpst Street, Arcata, CA 95521, USA
} 


\section{Resumen}

Antecedentes: El incremento en la frecuencia y tamaño de los incendios en décadas pasadas han causado preocupación sobre las poblaciones de especies que se reproducen estrictamente por semillas y que pueden ser vulnerables a fuegos repetidos a intervalos de tiempo cortos antes de que las mismas lleguen a su madurez. La susceptibilidad de las poblaciones a este riesgo depende parcialmente de la cantidad y características de la carga de combustible en el tiempo, y de su influencia sobre el comportamiento y efectos del fuego. Este estudio caracterizó la dinámica de los combustibles y modeló el comportamiento del fuego a través de una cronosecuencia después de incendios en rodales de una especie de conífera rara y serótina llamada ciprés de panadero (Baker cypress, Hesperocyparis bakeri [Jeps.] Bartel), cuyo rango de edades era desde 3 y hasta 147 años después de los incendios.

Resultados: El mantillo y los combustibles leñosos finos (1 a 100 h) fueron los mayores en los rodales de 10 y 147 años, mientras que los combustibles gruesos (1000 h) tuvieron un pico en los rodales de 10 años y decrecieron subsecuentemente con el tiempo en el post-fuego. La carga de hojarasca en descomposición (i.e., duff) se incrementó consistentemente desde el momento del incendio. La producción de conos no ocurrió en los 10 primeros años postfuego del desarrollo del rodal. El contenido de humedad foliar el ciprés de panadero se correlacionó inversamente con la edad del rodal, y las hojas más viejas tuvieron menor humedad que las nuevas. El comportamiento del fuego modelado en superficie fue mayor en los rodales de 10 y 107 años de acuerdo a la mayor carga de mantillo, material leñoso fino y acumulación de combustible de arbustos. Aunque el contenido de humedad foliar fue más alto en rodales más jóvenes e influenció la intensidad crítica de línea, no observamos cambios en el tipo de fuego.

Conclusiones: La carga del combustible fino en rodales de ciprés de panadero siguió en el tiempo una curva patrón del tipo U (primero decreciendo, luego estable, y posteriormente incrementándose), lo que es consistente con los resultados encontrados para otros bosques con regímenes de fuego que implican el reemplazo total de los rodales. Nuestros resultados indican que en los primeros estadios sucesionales post-fuego los rodales de ciprés de panadero tienen suficiente combustible como para permitir la propagación del fuego, y que rodales de 10 años de edad pueden arder con un comportamiento de mucha intensidad previo a la producción de conos. En lo posible, recomendamos suprimir los incendios en rodales menores a los 20 años de edad para evitar reducciones sustanciales o extinciones locales de estas poblaciones raras de cipreses de panadero. Nuestros resultados subrayan la importancia de conocer los patrones de producción de conos, la dinámica de los combustibles, y el correspondiente comportamiento del fuego de especies que se reproducen estrictamente por semillas, para determinar el riesgo de pérdidas de estas poblaciones debidas a los intervalos de fuego muy cortos.

\section{Introduction}

The quantity, quality, and arrangement of live and dead fuels in fire-prone forests are important drivers of fire behavior and effects. In many forest types, these fuel characteristics vary dramatically over time, a process referred to as fuel succession (Fahnestock 1976). Understanding the patterns of fuel succession can aid managers in making wildfire response decisions and developing better fuel management plans to meet resource objectives (Davis et al. 2009), such as managing for the persistence of rare, fire-dependent species. Given ongoing shifts in fire regime characteristics associated with climate change (Westerling 2016; Parks et al. 2017), managers must increasingly rely on fuel succession patterns to make informed decisions.

Fuel succession patterns in fire-prone forests are reflective of fire behavior and effects and the subsequent ability of fuels to accumulate over time. Few studies have examined longer-term fuel succession patterns following fire, but previous research has highlighted substantial variation within and among forest types (Brown and See 1981; Lotan et al. 1985). In forests that experience a high-severity fire, post-fire fuel succession typically has pulses of fine fuel accumulating during the early and late stages of stand development (Fahnestock 1976; Agee and Huff 1987; Kashian et al. 2013). However, other studies conducted in forests characterized by similar fire regimes, but with different climates, have found slower fuel recovery rates. In boreal forests of northern Sweden, fine fuel loading was slow to accumulate in the short term $(<30 \mathrm{yr})$ but progressively increased until reaching a steady state (Schimmel and Granström 1997). In subalpine forests of Yellowstone National Park, USA, fine-fuel loading was persistently low and contributed to limited fire potential over the first $100 \mathrm{yr}$ (Romme 1982). The slower accumulation of fuels over time following a high-severity fire in these ecosystem types is likely due to greater consumption of fine fuels in the fire-killed trees or slower vegetative regrowth that occurs in cooler, higher-latitude climates. By contrast, research examining subalpine forest stands between 22 and 258 yr in Alberta, Canada, found that fine-fuel loading was highly variable over stand age and demonstrated that fire 
weather had a greater direct effect on resulting fire behavior than fuel loading or stand age (Bessie and Johnson 1995).

Previous studies have focused primarily on surface and crown fuel loading changes with time since fire, while far less attention has been given to factors that may influence the moisture content of live fuels (Jolly and Johnson 2018). Changes in the live-fuel moisture content of shrubs and trees at different stand development stages may influence potential fire behavior. In fact, some young or recently burned stands experience a period of limited fire spread, presumably due to insufficient fuel (Romme 1982; Parks et al. 2015) or high live-fuel moisture (Catchpole and Catchpole 1991; Davies et al. 2009). Conversely, some ecosystems lack a strong fuel-age limitation in the recurrence of fire (Keeley et al. 1999a; Moritz et al. 2005). For instance, fire hazard in young chaparral stands $(\leq 20 \mathrm{yr})$ was $\sim 2.4 \%$ while fire hazard in 60-year-old stands only increased to $\sim 4.9 \%$, indicating that fire-weather conditions (e.g., Santa Ana winds) or sufficient vegetation regrowth (e.g., resprouting or fire-obligate shrubs) were more influential in promoting fire spread (Moritz et al. 2005). While it is widely known that new foliage has higher moisture content than older foliage (Agee et al. 2002; Keyes 2006), we are unaware of studies that have examined patterns of foliar moisture content with time since fire (i.e., stand age).

Given the recent shifts in many western US fire regimes toward more frequent and larger, high-severity fires (Miller et al. 2009; Westerling 2016; Parks et al. 2017), the persistence of certain species has become a point of concern (Turner 2010; Buma et al. 2013), especially for obligate-seeding species that take a long time to reach sexual maturity. While the prolonged absence of fire in obligate seeders can allow overstory transition to more shade-tolerant species (i.e., senescence risk), obligate seeders could also burn prior to the onset of seed production, eliminating the stand (i.e., immaturity risk; Keeley et al. 1999b). Previous studies have documented immaturity risk in many obligate seeders for which short-interval $(<40 \mathrm{yr})$ fires caused substantial decreases in populations (Zedler 1977; Zedler et al. 1983; Keeley et al. 1999b; de Gouvenain and Ansary 2006; Bowman et al. 2014; Fairman et al. 2017). The potential for immaturity risk to occur is partially dependent on how rapidly plants reach reproductive maturity (e.g., Enright et al. 1996). While some species produce reproductive structures quickly, many tree species can take a decade or more to do so. Information that characterizes the time to maturity in most species is largely lacking but is essential to determine the potential for immaturity risk under changing fire conditions. Along with increases in fire frequency, increased temperatures associated with climate change may result in extending the time to maturity (i.e., the time it takes an individual to produce viable seeds) due to reduced water availability, slowing growth, and thus potentially extending the duration of immaturity risk (Buma et al. 2013; Enright et al. 2015). However, the frequency with which these events might occur is unknown for most areas and previous observations of immaturity risk may simply represent accounts of low-probability events. Thus, understanding fuel and fire behavior changes can provide further insight into the potential impacts following a short-interval fire.

Baker cypress (Hesperocyparis bakeri [Jeps.] Bartel) is a rare, serotinous conifer (Milich et al. 2012) classified as "vulnerable" by the International Union for Conservation of Nature (Farjon 2013). Currently, there are 11 extant and disjunct populations, with the oldest stand approximately 156 years old at the time of this study (Merriam and Rentz 2010; Bower and Hipkins 2017). Given their serotinous character, retention of lower branches, relatively even-aged structure, and other characteristics, Baker cypress forests are typically classified as having a low-frequency, high-severity fire regime (Skinner and Taylor 2018), although fire history studies quantifying the fire regime characteristics for this species have not been conducted. Following fire, mature Baker cypress will typically die because the heat is sufficient to kill the cambium beneath their thin bark. The heat of the fire also serves to release seeds from the serotinous cones that disperse onto fire-exposed mineral soil and facilitate the establishment of the next cohort. Forest types adjacent to Baker cypress are quite varied, with some having more frequent, low- to mixedseverity fire regimes, such as mixed-conifer, ponderosa pine (Pinus ponderosa Douglas ex Lawson \& C. Lawson), and red fir (Abies magnifica A. Murray bis) forests, and others having less frequent, mixed- to highseverity fire regimes, such as lodgepole pine (Pinus contorta ssp. murrayana [Grev. \& Balf.] Critchf.) forests.

In the prolonged absence of fire, these forests are prone to senescence risk because shade-tolerant competitors can overtop and kill mature Baker cypress (Merriam and Rentz 2010), but the extent of this occurrence is not well characterized. However, many sites contain lowproductivity soils (serpentine, volcanic lava flows) that inhibit substantial recruitment of competing conifers and likely act as refugia from the influence of fire exclusion. Seeds can release upon tree death, but the presence of a dense litter and duff layer often inhibits seed germination and survival. While some Baker cypress populations have experienced a prolonged period of fire exclusion that has caused senescence (Merriam and Rentz 2010), six of the nine California, USA, populations have burned in large wildfires since 2006 (J.M. Kane, Humboldt State University, Arcata, California, USA, unpublished data), prompting concern about the potential for short-interval fires that may facilitate population reduction or loss. 
This study examined post-fire fuel succession patterns in the rare, serotinous Baker cypress of northern California, across a time-since-fire chronosequence ranging from 3 to 147 years. The specific objectives of this study were to (1) characterize surface fuel loading by category (e.g., litter, duff, woody fuels, etc.) across the chronosequence; (2) examine changes in foliar moisture content of shrubs and trees across the chronosequence;(3) determine the amount of cone production across the chronosequence; and (4) model changes in predicted fire behavior across the chronosequence. While our research focused on the rare, serotinous Baker cypress, results from this study may have implications for the many other obligate-seeder species in fire-prone ecosystems.

\section{Methods}

\section{Experimental design}

The study took place in Baker cypress populations occurring in Shasta, Siskiyou, and Plumas counties of northeastern California, USA. Stand selection for this study was based on a current map of Baker cypress populations (K. Merriam, USDA Forest Service, Quincy, California, USA, unpublished data) overlaid with fire perimeter data (CalFire 2018) so that we could survey a wide range of time since fire and stand development stages in Baker cypress ecosystems (Fig. 1). Since the 147-year-old stand preceded fire records, we approximated time since fire based on a tree-ring count of the oldest tree cored at the site during a stand inventory that we conducted in 2016. Attempts to
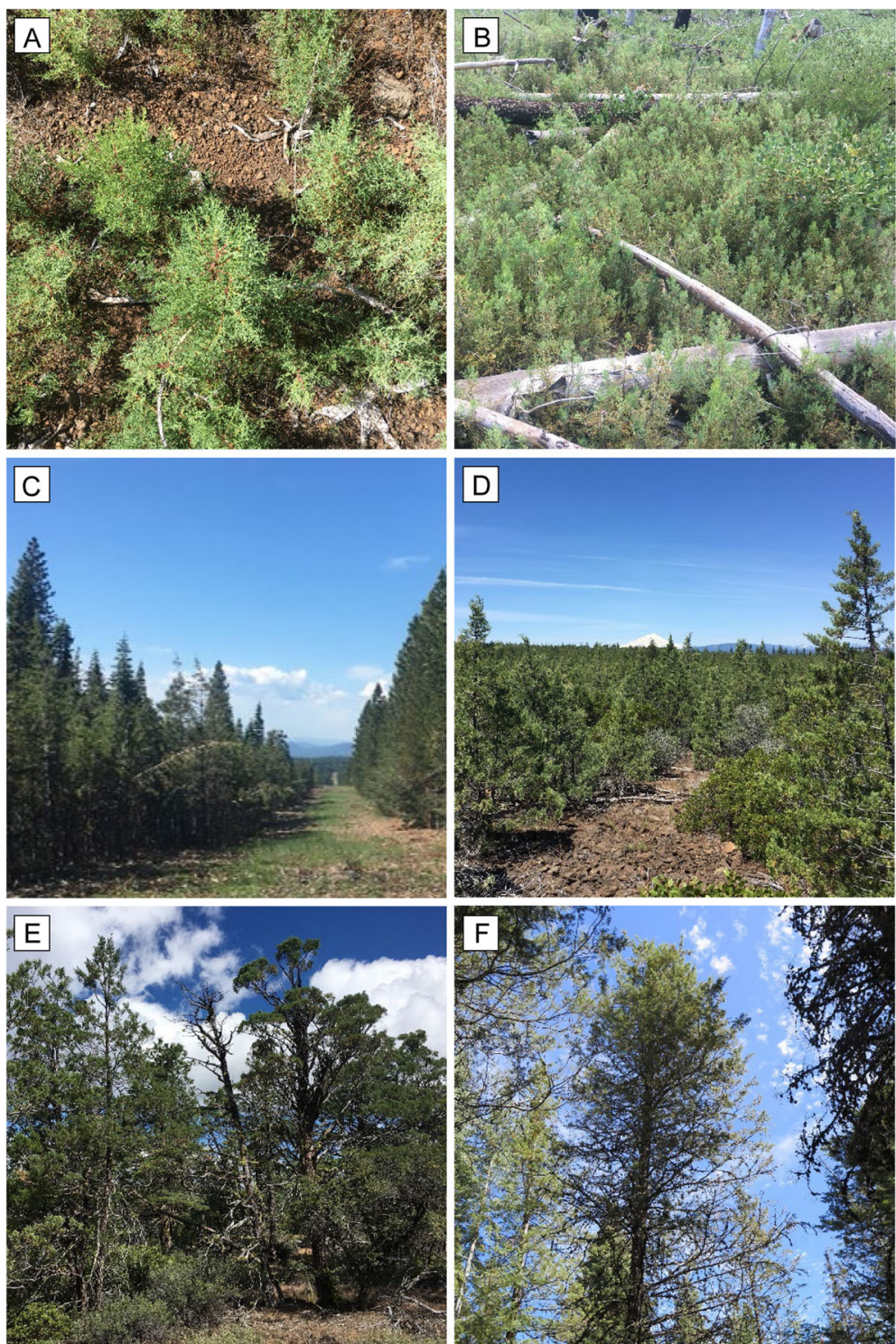

Fig. 1 Representative Baker cypress stand conditions for our study sites along the time-since-fire chronosequence in northern California, USA, that were sampled in 2015 or 2016. Stand ages include (A) 3 yr, (B) 10 yr, (C) 26 yr, (D) 40 yr, (E) $107 \mathrm{yr}$, and (F) 147 yr. Photographer credits: (A through E) B. McNamara; (F) J. Kane 
cross-date tree rings at this site were unsuccessful, thus our age estimate for this site may be conservative. An additional 26-year-old planted stand adjacent to the 147-year-old stand was included for some measurements (e.g., foliar moisture content, cone production) as it offered us the opportunity to add an important stand age that was otherwise not available.

Similar to many previous studies on fuel succession, we employed a chronosequence approach that substitutes time for space to examine potential changes in fuel characteristics and cone production. While we recognized the limitations of the chronosequence approach (Walker et al. 2010), we minimized these impacts by selecting stands that had similar site characteristics. Slope and aspect for each site were derived using raster data from a $10 \mathrm{~m}$ resolution digital elevation model within a geographic information system. We used this information to select study sites that had minimal variation in among-site topographical characteristics, resulting in all study sites having gentle to moderate slopes and generally north-facing aspects (Table 1). All soil types were volcanic in origin; however, the 40 and 107year-old sites at Timbered Crater Wilderness Study Area in northeastern California, USA, contain lava flows with younger and presumably lower-productivity soils than the other sites. Greenleaf manzanita (Arctostaphylos patula Greene) was the dominant or codominant shrub species at most sites, with the exception of the 10-year-old stand where tobacco brush (Ceanothus velutinous Douglas) was the most common shrub. Stand density index was calculated based on Reineke (1933), and values increased with time since fire (Table 1). At the oldest study site, which had substantial Baker cypress mortality among the canopy trees due to overtopping by other species, the stand density index was 492. This value is consistent with heavy competitioninduced mortality in other shade-intolerant species (Woodall et al. 2005).

\section{Data collection and calculations}

We first conducted a stand inventory within a 12 ha area at the 147-year-old site in 2016 using a systematic grid design containing sixteen 0.025 ha, fixed-area circular plots (radius $=8.92 \mathrm{~m}$ ) that were spaced $40 \mathrm{~m}$ apart. Plot locations for the remaining sites surveyed in 2017 were generated from 25 random points in ArcMap 10.2 (ESRI, Redlands, California, USA) within a 12- to 15-hectare area. Of the original 25 selected points, we established twelve 0.025 ha fixed-area circular plots (radius $=8.92 \mathrm{~m}$ ) that contained live or dead Baker cypress and had an average minimum distance of $59 \mathrm{~m}$ (range 5.8 to $195.9 \mathrm{~m}$ ) from another plot. Within each plot, we recorded species, status (live or dead), height, and crown base height for all trees $>3 \mathrm{~cm}$ diameter at breast height $(\mathrm{DBH})$, while smaller trees $(<3 \mathrm{~cm} \mathrm{DBH})$ were simply tallied.

Surface fuel loading data at all sites were collected using the planar intercept method (Brown 1974). At the 3-, 10-, 40-, and 107-year-old sites, $16 \mathrm{~m}$ planar intercept transects were established along random azimuths originating at the center of each tree plot. In every third tree plot, we established a second planar intercept transect that was $90^{\circ}$ from the first transect, for a total of 16 transects per stand age. At the 147-year-old site, data was collected the previous year with slightly different methods: we used two $12 \mathrm{~m}$ transects originating at the center of each tree plot (32 total), with the first planar intercept being a randomly selected azimuth from plot center and the second being established $120^{\circ}$ from the first. Coarse woody fuels (1000hour, $>7.62 \mathrm{~cm}$ ) were recorded along the full transect length, 100-hour fuels $(2.54$ to $7.62 \mathrm{~cm})$ were counted along the first half of the transect, and 1-hour $(<0.63 \mathrm{~cm})$ and 10-hour $(0.63$ to $2.54 \mathrm{~cm})$ fuels were counted along the first quarter of the transect in all stands. Litter and duff depths were measured at the quarter, half, and full mark length of each transect. The highest fuelbed depth (to a maximum of $2 \mathrm{~m}$ height) was also measured three times per transect along $1 \mathrm{~m}$ planes preceding the quarter, half, and full transect length marks. For all 1000-hour fuel particles, we measured the diameter where the particle intersected the transect, categorized each as rotten or sound, and identified each to species. Live surface fuels, including shrubs and herbaceous plants, were collected in a $1 \mathrm{~m}^{2}$ circular plot at the end of all 32 transects for the 147-yearold site, and at the end of nine systematically selected transects for the remaining sites. Live surface fuels collected for each plot were separated into woody shrub or

Table 1 Site attributes at each Baker cypress stand measured along a chronosequence in northern California, USA, surveyed in 2015 or 2016 Note that the Pipeline site was planted and excluded from fuel loading and stand density measurements. $\mathrm{SDI}=$ stand density index, $\mathrm{n} / \mathrm{a}=$ not available

\begin{tabular}{|c|c|c|c|c|c|c|c|}
\hline Fire or site name & Latitude, longitude $\left(^{\circ}\right)$ & Age (yr) & Aspect $\left({ }^{\circ}\right)$ & Slope (\%) & Elevation (m) & Metric SDI & Cones per tree $(n)$ \\
\hline Eiler & $40.76,-121.6$ & 3 & 27 & 8 & 1560 & 0 & 0 \\
\hline Moonlight & $40.18,-120.7$ & 10 & 5 & 23 & 2034 & 22 & 0 \\
\hline Pipeline & $40.78,-121.7$ & 26 & 336 & 8 & 1344 & $\mathrm{n} / \mathrm{a}$ & 120 \\
\hline Horrs Corner & $41.18,-121.5$ & 40 & 13 & 7 & 1130 & 94 & 210 \\
\hline Glass Mountain & $41.19,-121.8$ & 107 & 333 & 1 & 1098 & 210 & 240 \\
\hline Burney & $40.78,-121.7$ & 147 & 336 & 8 & 1344 & 492 & 1290 \\
\hline
\end{tabular}


herbaceous categories and all samples were dried for at least $72 \mathrm{hr}$ at $60^{\circ} \mathrm{C}$, weighed, and values were converted to megagrams per hectare $\left(\mathrm{Mg} \mathrm{ha}^{-1}\right)$.

We calculated fuel loading $\left(\mathrm{Mg} \mathrm{ha}^{-1}\right)$ for 1 - to 100hour fuels (Eq. 1) and 1000-hour fuels (Eq. 2) using values for particle diameter, particle angle, and specific gravity of conifers provided by Brown (1974):

Fine Fuel Loading $=\frac{\left(1.234 \times n \times d^{2} \times s \times a\left(\sqrt{1+\left(\frac{\% \text { slope }}{100}\right)^{2}}\right)\right)}{N l}$

Coarse Fuel Loading $=\frac{\left(1.234 \times \sum d^{2} \times s \times a\left(\sqrt{1+\left(\frac{\% \text { slope }}{100}\right)^{2}}\right)\right)}{N l}$,

where $n$ signifies the number of particles intercepted, $d$ is the particle diameter, $s$ is the particle specific gravity, $a$ is the particle angle correction factor, and $N l$ is the transect length.

Litter and duff loading $\left(\mathrm{Mg} \mathrm{ha}^{-1}\right)$ were calculated following Eq. 3:

$$
\text { LitterandDuffLoading }=(D \times B D V) \times 10 \text {, }
$$

where $D$ represents depth in meters $(\mathrm{m})$ and $B D V$ is the bulk density value in kilograms per cubic meter $\left(\mathrm{kg} \mathrm{m}^{-3}\right)$. Since bulk density values for Baker cypress were not available in the literature, we used the average values of scaleneedled conifers from the Sierra Nevada, California, USA (van Wagtendonk et al. 1998), for both duff $\left(173.7 \mathrm{~kg} \mathrm{~m}^{-3}\right)$ and litter $\left(118.6 \mathrm{~kg} \mathrm{~m}^{-3}\right)$ loading estimates.

Crown fuel characteristics were determined based on field observations and model estimates for each plot across all sites. We measured tree height and crown base height in the field and calculated the average crown base height across all plots for each site. Average crown bulk density was determined using Fuels Management Analyst Plus (FMA+; Carlton 2005), based on species and the diameter distribution across all plots for each site. Since crown mass equations were not available for Baker cypress, we used western juniper (Juniperus occidentalis Hook.) values as a proxy since it was the species with the most similar crown characteristics available.

In 2017, live foliage was collected from 10 trees and shrubs at each of the six sites between 14 and 17 August, which is in the driest time of the wildfire season for this region. For each site, tree and shrub collections occurred within approximately 1 - to 2 -hectare area of the broader fuel sampling areas mentioned above. We chose a smaller area for live fuel sampling because we wanted to limit potential differences in climate conditions over time across sites. Live foliage samples were collected within $2 \mathrm{~m}$ from the ground on the south side of each tree to minimize variation associated with crown position (Richardson et al. 2000). All sampling occurred between 1200 and 1600 hours to limit variation caused by daily moisture fluctuations (Zahn and Henson 2011). New ( $<1 \mathrm{yr})$ and old $(>1$ yr) foliage were separately collected to account for established differences in foliar moisture content amongst foliage ages (Van Wagner 1967; Chrosciewicz 1986). For each of the 10 trees that were sampled for fuel moisture, we also counted all cones on each tree, using binoculars when needed, to approximate average cone production per tree for each site. We also collected live foliage samples from 10 specimens of the dominant shrub species at each site or from five samples of the codominant shrub species per site. Foliage samples were contained within airtight plastic bags and kept on ice until weighed (Zahn and Henson 2011). The wet weight of each sample was obtained by subtracting the empty bag weight from the weight of the sealed bag containing foliage $\left(W_{1}\right)$. Subsequently, all samples were dried for $72 \mathrm{hr}$ at $60{ }^{\circ} \mathrm{C}$ and reweighed $\left(W_{\mathrm{d}}\right)$. Fuel moisture, expressed as a percentage, was calculated using Eq. 4 (Gary 1971).

$$
\text { Fuel Moisture Content }=\frac{W_{1}-W_{\mathrm{d}}}{W_{\mathrm{d}}} \times 100 \text {. }
$$

\section{Modeling and statistical analyses}

We used a locally estimated scatterplot smoothing (Loess) function to visualize the non-linear patterns of fuel loading across the time-since-fire chronosequence. Loess fits were made at $1 \mathrm{yr}$ increments from 0 to $150 \mathrm{yr}$ since fire for each fuel type including duff, litter, shrubs, and 1through 1000-hour woody fuels. The resultant patterns represented estimated surface fuel loads based on the collective change of fuel inputs and outputs over time.

Live foliar moisture content patterns for shrubs and Baker cypress foliage were analyzed using simple linear and multiple regression. Each individual sampled tree or shrub was considered an independent replicate to account for variation in live foliar moisture content associated with differences among trees within a site (e.g., physiological, competitive environment). We examined the influence of time since fire for shrub foliar moisture content and the influence of time since fire and foliage age, including an interaction term, for Baker cypress foliar moisture content. Model selection for Baker cypress foliage was determined using the change in Akaike Information Criterion ( $\triangle \mathrm{AIC}$; Burnham and Anderson 1998), a common indicator of model quality relative to 
other models. The top regression model was selected based on the lowest AIC value and we report the resultant $F$ - and $t$-statistics. Foliar moisture content data were logtransformed in order to meet parametric model assumptions. Model predictions of foliar moisture content across the chronosequence were back-transformed in visual plots for interpretability. All statistical analyses were conducted in the $R$ environment ( $R$ Development Core Team 2018).

We used BehavePlus version 6 (Andrews 2014) to assess potential surface and crown fire behavior in Baker cypress stands. We reported surface fire rate of spread and flame length based on the Rothermel (1972) fire spread equations. This model assumes that fuels are evenly distributed throughout a stand and that fire behavior is temporally static (i.e., consistent over time). Potential fire behavior was modeled across the time-sincefire chronosequence of Baker cypress stands using field and model-based observations of slope, fuel characteristics, fuel moisture, and wind speed. Slope at our study sites ranged from 1 to $23 \%$; we used a value of $8 \%$, the average slope across all sites, for all model runs. For the 107-year-old stand, we used a fuelbed depth of $0.3 \mathrm{~m}$ because of the prevalence of a shrub fuel layer. We used both custom fuel models generated from observed fuel characteristics at each site and representative fire behavior fuel models from a subset of Scott and Burgan (2005). Fire behavior fuel models were selected by a combination of observed fuel characteristics (primarily fuelbed depth and fine woody fuel loading) and our expectations of how fire might carry through the respective stands under the modeled fire-weather conditions. As a result, we used low-load shrub models, $\mathrm{SH} 1$ and $\mathrm{SH} 2$, to characterize the two youngest stands, 3- and 10-year-old stands, respectively. The 40-year-old stand was modeled using TU1, while the 107-year-old stand was modeled with TU5. The oldest stand (147 yr) was characterized by relatively high fuel loads and fuelbed depth due to substantial Baker cypress mortality and was modeled using a slashblowdown model, SB3. The custom fuel models used for each site were initialized from the selected Scott and Burgan (2005) fire behavior fuel models, including surface areato-volume ratios (1-hour, herbaceous, and shrub fuels), heat content, and moisture of extinction. The main difference was that we modified these models to include field-based observations of fuel loading by type and fuelbed depth.

To model fire behavior, we extracted fire-weather data for each Baker cypress field site from gridMET, a $4 \mathrm{~km}$ surface meteorological dataset available on a daily time scale from 1979 to the present for the contiguous US (climatologylab.org; Abatzoglou and Brown 2012; Abatzoglou 2013) and accessed through Google Earth Engine (earthengine. google.com/datasets). From this data, we calculated the $97^{\text {th }}$ percentile $10 \mathrm{~m}$ wind speed, maximum temperature, minimum relative humidity, and 100-hour fuel moisture for the wildfire season (June through September) between 2000 and 2017. The $10 \mathrm{~m}$ wind speeds were then adjusted to estimate mid-flame wind speeds following the equation provided by Andrews (2012) to account for differences in stand and fuelbed characteristics among sites. Wind adjustment factor (WAF) accounts for fuelbed depth $(H)$, canopy closure $(C C)$ and crown ratio $(C R)$, depending on whether sites were unsheltered $\left(W A F_{\mathrm{u}} ; \mathrm{Eq} .5\right)$ or sheltered (WAF ; Eq. 6):

$$
\begin{aligned}
W A F_{\mathrm{u}} & =\frac{1.83}{\ln \left(\frac{20+0.36 H}{0.13 H}\right)} . \\
W A F_{\mathrm{s}} & =\frac{1.83}{\sqrt{\frac{C C}{3} \times C R \times H} \ln \left(\frac{20+0.36 H}{0.13 H}\right)} .
\end{aligned}
$$

Using minimum relative humidity $(R H)$ and maximum temperature (TEMP), we calculated the equilibrium moisture content $(E M C)$ based off the equation provided by Cohen and Deeming (1985) that is used as part of the National Fire Danger Ratings System (Eq. 7) as well as FireFamilyPlus (Bradshaw and McCormick 2000):

$E M C=[0.03229+(0.281073 \times R H)]-(0.000578 \times T E M P \times R H)(7)$

After calculating $E M C$, we multiplied $E M C$ by either 1.03 or 1.28 to estimate 1 - and 10-hour fuel moisture, respectively. The $97^{\text {th }}$ percentile fine woody fuel moisture content was $2.2 \%, 2.7 \%$, and $5.1 \%$ for $1-, 10-$, and 100-hour fuels, respectively. Shrub fuel moisture inputs were based on fuel moisture samples collected from each site and herbaceous fuel moisture content was set at $30 \%$. The $97^{\text {th }}$ percentile wind adjusted speeds used for fire behavior modeling were 6.2, 6.7, 6.7, 7.8, and $3.7 \mathrm{~km} \mathrm{hr}^{-1}$, for each stand in order of increasing stand age.

Representation of crown fire behavior was estimated based on calculations of critical fireline intensity following Van Wagner (1977). This measure represents the fire intensity necessary for transition from surface fire to crown fire. Determination of the fire type (surface, passive crown, conditional crown, and active crown fire) was based on the equation of Scott and Reinhardt (2001), which was selected due to its ability to better estimate the incidence of active crown fires (Scott 2006). We also provided predicted crown fire flame length and rate of spread. Additionally, we modeled potential post-fire tree mortality based on the average stand characteristics for each site with the First Order Fire Effects Model version 6.5 (Lutes 2019), 
which predicts mortality based on bark thickness estimates specific to tree species by DBH and percent crown volume scorched. Since bark thickness estimates are not available for Baker cypress, we used western juniper as a proxy based on its similar bark thickness characteristics. Crown volume scorched was based on scorch height, tree height, and crown ratio.

\section{Results}

\section{Fuel loading patterns}

Litter and fine woody fuel (1- to 100-hour) loading was highest in the 10- and 147-year-old stands (Table 2, Fig. 2), but were lowest in the 3-year-old stand. Fine-fuel loading was lower in the 40- and 107-year-old stands compared to the 10- or 147-year-old stands. Coarse woody fuel loading was low initially, and peaked in the 10-year-old stand. After $10 \mathrm{yr}$, coarse woody fuel loading followed a decreasing trend. We did not observe any duff in the 3-year-old stand, after which duff loading increased with time since fire. Live shrub fuel loading was more variable over time (Table 2), with the highest values recorded at the 10- and 107 -year-old stands. Herbaceous fuel loading was persistently low across all stands, but 333\% higher in the 3-yearold stand compared to the 10-year-old stand, which had the lowest herbaceous fuel loading.

Crown fuels were not present in the 3- and 10year-old stands because of the low stature of the existing seedlings and saplings and we did not encounter any trees that survived the preceding wildfire within our study sites. Crown base height was $1 \mathrm{~m}$ in the 40-year-old stand, increasing to 3 to $4 \mathrm{~m}$ in the older stands. Estimates of crown bulk density ranged from 0.43 to $0.88 \mathrm{~kg} \mathrm{~m}^{-2}$, with the oldest stand having the highest value.

\section{Live fuel moisture patterns}

Live fuel moisture patterns varied along the timesince-fire chronosequence. Average observed shrub foliar moisture content ranged from 74 to $107 \%$ across sites and was highest at the 147- and 3-year-old stands and lowest in the 40- and 107-year-old stands (Table 2), but differences were not linearly related to time since fire $(P=0.74)$. Average live foliar moisture content for Baker cypress ranged from 72 to $143 \%$ in old foliage and from 89 to $169 \%$ in new foliage, across all sites. The 40-year-old stand had the lowest observed foliar moisture values and the two youngest stands (3- and 10-year-old) had the highest foliar moisture content (Fig. 3). Foliar moisture content in new foliage $(<1 \mathrm{yr})$ was 9 to $59 \%$ higher than older foliage ( $>1 \mathrm{yr}$ ) across the chronosequence (Fig. 3). An additive model that included stand age and foliage age better predicted Baker cypress live foliar moisture content than models of either variable alone or with an interaction between stand and foliage age. Time since fire had a strong and negative relationship with live foliar moisture content $\left(\mathrm{R}^{2}=0.42, P<0.0001\right.$; Table 3).

\section{Cone production}

Cone production in Baker cypress increased with time since fire across all stands (Table 1). However, we did not observe cone production in either of the two youngest stands (3- and 10-year-old). The 26-year-old stand, by contrast, had an average of 120 cones per tree. The two intermediate-aged stands, 40- and 107-year-old, had 210 and 240 cones per tree, respectively. The oldest stand had substantially more cone production, with an average of 1290 cones per tree.

Table 2 Fuel characteristics along a time-since-fire chronosequence of Baker cypress stands in northern California, USA, surveyed in 2015 or 2016. Values were used to parameterize fire behavior models. Values in parentheses are standard error. FMC = foliar moisture content

\begin{tabular}{|c|c|c|c|c|c|}
\hline \multirow[b]{2}{*}{ Fuel characteristic } & \multicolumn{5}{|c|}{ Time since fire $(\mathrm{yr})$} \\
\hline & 3 & 10 & 40 & 107 & 147 \\
\hline 1-hour $\left(\mathrm{Mg} \mathrm{ha}^{-1}\right)$ & $0.07(0.02)$ & $0.31(0.06)$ & $0.2(0.04)$ & $0.27(0.04)$ & $0.90(0.11)$ \\
\hline 10-hour $\left(\mathrm{Mg} \mathrm{ha}^{-1}\right)$ & $1.11(0.30)$ & $2.87(0.53)$ & $0.74(0.16)$ & $1.29(0.26)$ & $4.25(0.48)$ \\
\hline 100-hour (Mg ha-1) & $3.26(0.88)$ & $8.29(1.45)$ & $0.55(0.28)$ & $2.02(0.44)$ & $3.37(0.63)$ \\
\hline 1000-hour, sound $\left(\mathrm{Mg} \mathrm{ha}^{-1}\right)$ & $12.03(3.25)$ & $118.07(12.75)$ & $10.01(4.10)$ & $14.37(5.34)$ & $9.49(2.35)$ \\
\hline 1000-hour, rotten $\left(\mathrm{Mg} \mathrm{ha}^{-1}\right)$ & $0.00(0.00)$ & $8.65(4.25)$ & $7.27(2.90)$ & $8.84(4.07)$ & $0.82(0.39)$ \\
\hline Litter $\left(\mathrm{Mg} \mathrm{ha}^{-1}\right)$ & $1.63(0.67)$ & $12.45(3.56)$ & $9.66(2.25)$ & $12.08(2.10)$ & $26.51(4.07)$ \\
\hline Duff $\left(\mathrm{Mg} \mathrm{ha}^{-1}\right)$ & $0.00(0.00)$ & $8.21(2.40)$ & $9.77(3.06)$ & $27.39(5.99)$ & $86.35(12.41)$ \\
\hline Live herbaceous ( $\mathrm{Mg} \mathrm{ha}^{-1}$ ) & $0.5791(0.25)$ & $0.0042(<0.01)$ & $0.0162(0.01)$ & $0.1741(0.07)$ & $0.0146(<0.01)$ \\
\hline Live shrub $\left(\mathrm{Mg} \mathrm{ha}^{-1}\right)$ & $2.62(0.80)$ & $9.74(2.97)$ & $2.76(2.06)$ & $8.85(5.14)$ & $0.86(0.31)$ \\
\hline Shrub FMC (\%) & $101.81(2.84)$ & $104.27(2.36)$ & $84.98(3.77)$ & $73.82(1.44)$ & $107.16(2.82)$ \\
\hline Fuelbed depth (cm) & $20.34(4.40)$ & $31.22(4.35)$ & $6.64(1.77)$ & $6.64(1.20)$ & $37.28(5.87)$ \\
\hline
\end{tabular}



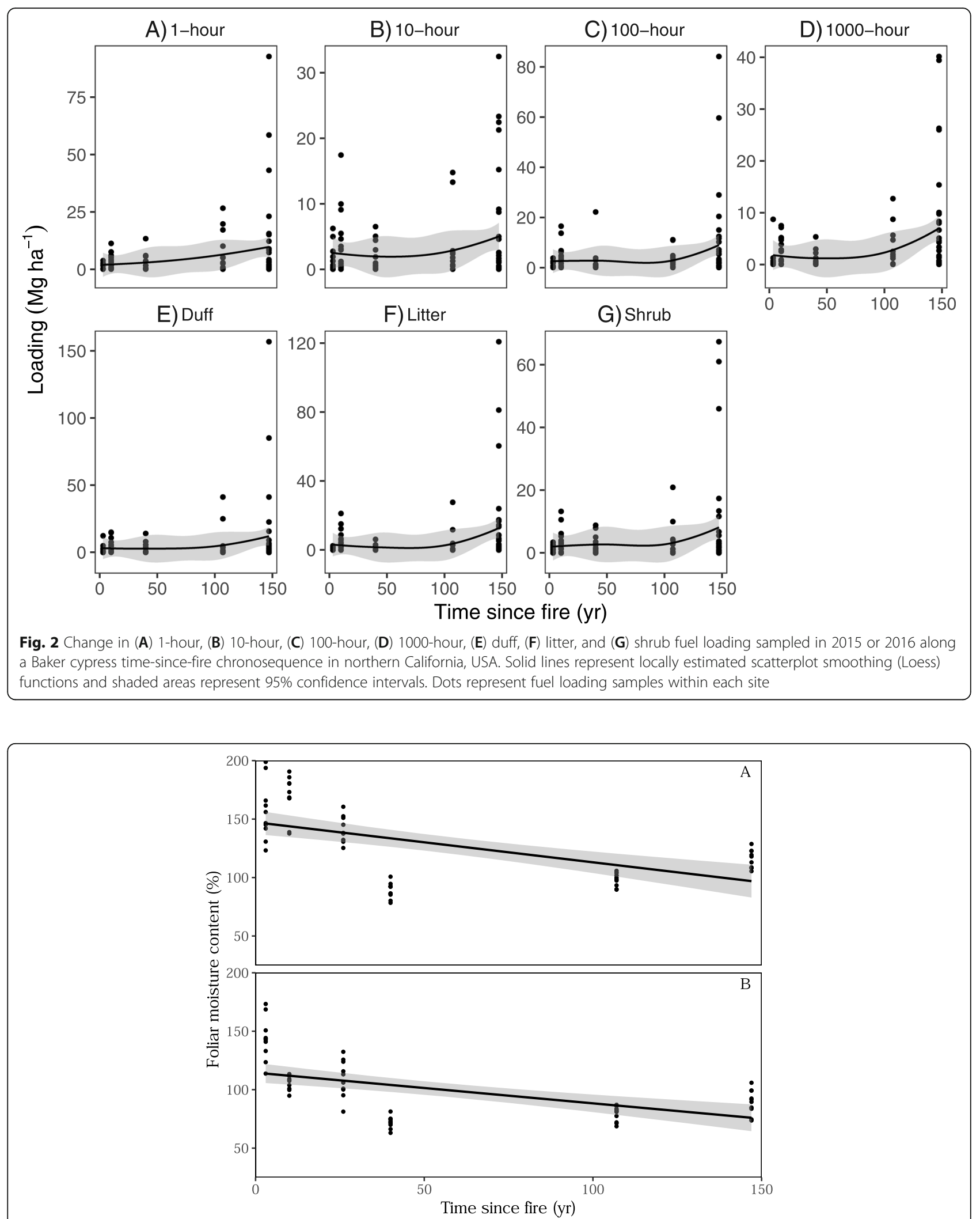

Fig. 3 Top model predictions of (A) new foliage ( $<1 \mathrm{yr})$, and (B) old foliage ( $>1 \mathrm{yr}$ ) live foliar moisture content (\%) collected in August 2016 across the Baker cypress time-since-fire chronosequences of northern California, USA. Dots represent observed foliar moisture content values of individual tree samples within each site 
Table 3 Summary of the top multiple regression model for Baker cypress live foliar moisture content that included foliage age and stand age. Sites were sampled in August 2016 and located in northern California, USA. Old $=$ foliage $>1$ yr, F-statistic $=42.44$ on 2 and 117 degrees of freedom, $\left(R^{2}=0.42, P<0.0001\right)$. SE represents standard error

\begin{tabular}{lcccc}
\hline Coefficients & Estimate & SE & t-statistic & $P$ \\
\hline Intercept & 4.9592 & 0.0345 & 143.7 & $<0.001$ \\
Stand age & -0.0025 & 0.0004 & -6.7 & $<0.001$ \\
Foliage age-Old & -0.2489 & 0.0393 & -6.3 & $<0.001$ \\
\hline
\end{tabular}

\section{Fire behavior and mortality patterns}

Potential fire behavior varied with time since fire across all stands. Potential surface fire behavior in Baker cypress followed a trajectory similar to that of the changes observed in fine fuels, with higher flame lengths and faster rates of spread occurring in the 10- and 147-year-old stands (Fig. 4). Surface flame length and rate of spread increased from $0.9 \mathrm{~m}$ and $1.6 \mathrm{~m} \mathrm{~s}^{-1}$, respectively, in the 3-year-old stand to $2.3 \mathrm{~m}$ and $3.5 \mathrm{~m} \mathrm{~s}^{-1}$, respectively, in the 10-year-old stand, based on custom model results. We would assume that this fire behavior would result in substantial mortality of Baker cypress in these young stands; however, modeled mortality estimates were not available for the small trees $(<1.37 \mathrm{~m}$ in height $)$ at these two sites. Potential flame lengths based on custom models decreased from $3.5 \mathrm{~m}$ in the 10-year-old stand to $0.03 \mathrm{~m}$ in the 40-year-old stand, although a conditional crown fire was predicted for the latter stand. The 107-yearold stand was predicted to sustain an active crown fire with a substantial increase in surface flame length and rate of spread compared to the 40-year-old stand. The oldest stand (147 yr) also was predicted to sustain an active crown fire. Crown fire rate of spread was predicted to be $11.9 \mathrm{~m} \mathrm{~s}^{-1}$ for the three oldest stands, and predicted crown fire flame length increased from $10.6 \mathrm{~m}$ in the 40-year-old stand to $22.8 \mathrm{~m}$ in the 147-year-old stand. Surface and crown fire behavior between custom models and fire behavior fuel models was largely in agreement, but custom models predicted slightly greater rates of spread and flame lengths at most sites (Fig. 4). Post-fire mortality was estimated to be $100 \%$ for all stands 40 yr or older based on custom fuel model inputs and modeled fire behavior. Modeling fire behavior using observed live Baker cypress foliar moisture content for woody fuels did not substantially change predictions of fire type (surface or crown fire). However, the critical fireline intensity values based on observed foliar moisture content were 14 and $23 \%$ lower for the 40- and 107-year-old stands, respectively, than estimates based on the standard use of $100 \%$ foliar moisture content.

\section{Discussion}

\section{Fuel loading patterns}

The patterns of fuel succession in Baker cypress were consistent with previous findings from other empirical studies following stand-replacing fire, providing further evidence that time since fire or stand age can be a useful predictor of fuel patterns over time (Fahnestock 1976; Brown and See 1981; Agee and Huff 1987). Fine-fuel loading across the 147-year chronosequence in our study indicated a Ushaped pattern. The first major surface fuel contributions likely resulted from the decaying of fire-killed snags, as observed through the substantial pulse of fine and coarse woody fuels in the 10-year-old stand. Other studies corroborate this initial pulse in the first post-fire decade (Agee and Huff 1987; Kashian et al. 2013; Dunn and Bailey 2015). The second major contribution to dead woody surface fuel loading was likely the result of competition-induced mortality that developed from the post-fire cohort of this very shade-intolerant species. Interspecific competition from more shade-tolerant species may accelerate the fuel accumulation process in Baker cypress stands of sufficiently advanced age and declining health (i.e., senescence risk), an on-going conversion observed in some of the older Baker cypress populations (Merriam and Rentz 2010). The lower fine woody fuel loads observed within the 40- and 107year-old stands likely reflects decomposition of dead woody fuels without substantive inputs from the new stand. However, these two stands possibly differed in their productivity compared to the others, due to the younger, less productive volcanic substrate (i.e., lava flows) that was present at these two sites, which may have partially contributed to the lower fuel loads at these intermittent stand ages. While the 107year-old stand lacked substantial fine woody surface fuels, an increase in shrub fuel loading was observed at this site.

\section{Live fuel moisture patterns}

Live foliar moisture content at the stand scale in Baker cypress generally decreased with stand age independent of foliage age - a finding, to our knowledge, that has not been previous reported. We speculate that increased competition for water in a moisture-limited ecosystem may be one possible mechanism for this trend. In our study, we observed increases in stand density index, and thus live tree biomass, with time since fire, suggesting increased competition for soil moisture and other nutrients during the dry northeastern California summer. Changes in foliar anatomy and physiology with tree age may have also contributed to these observed patterns. For instance, the amount of non-photosynthetic cell area within a needle decreased with tree age in Douglas-fir (Pseudotsuga menziesii [Mirb.] Franco; Apple et al. 2002), and thus needles in younger trees may require more water storage (i.e., higher foliar moisture content) to maintain what is presumably a higher rate of photosynthetic activity. There is greater recognition that physiological changes, possibly in association with tree age, can strongly influence patterns of foliar moisture content (Jolly and Johnson 2018), but this topic requires further investigation. 

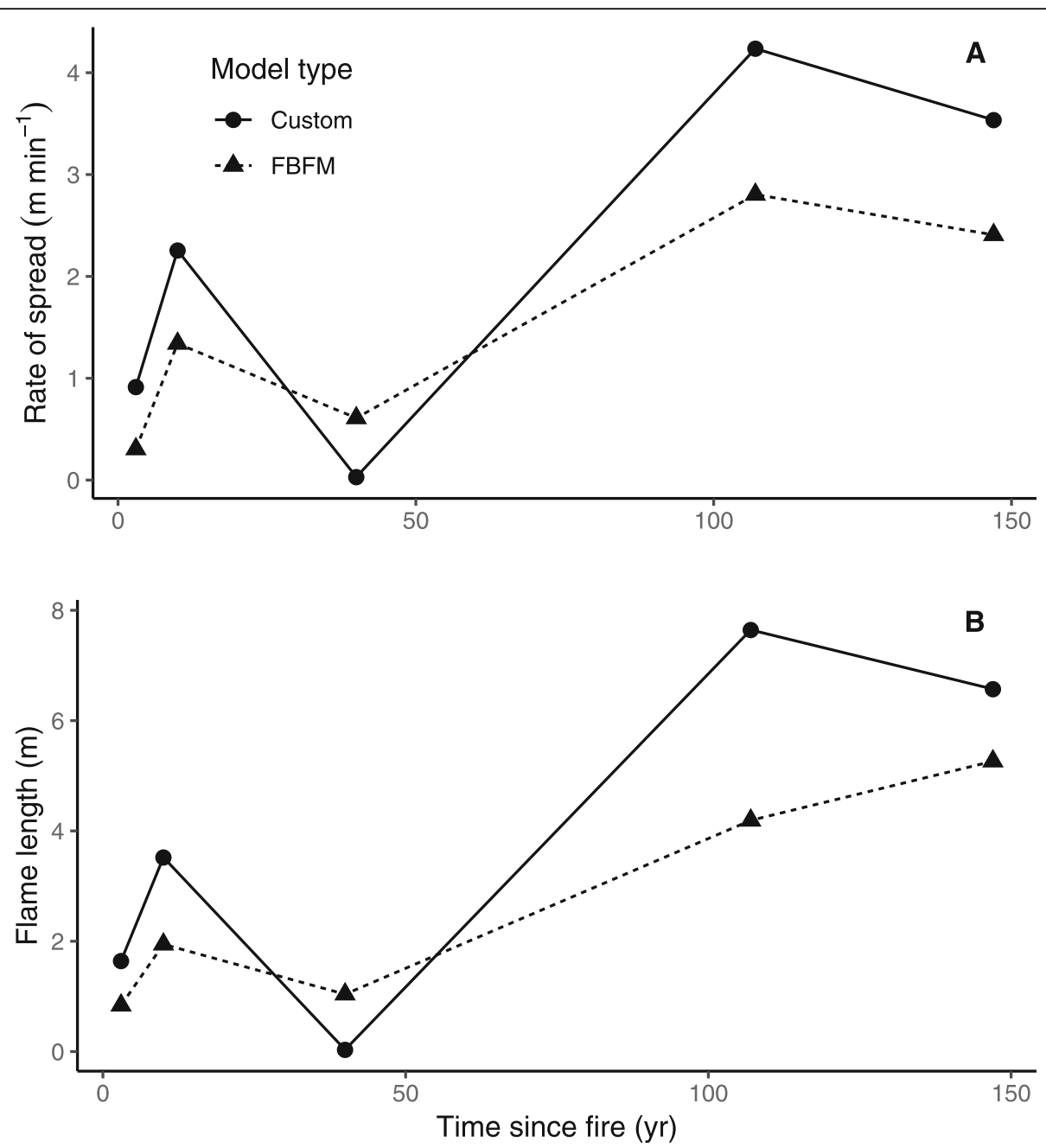

Fig. 4 Modeled surface fire behavior, (A) rate of spread and (B) flame length, across a time-since-fire chronosequence of Baker cypress stands in northern California, USA. Predictions are based on predictions from custom fuel models (solid line and dots) generated from field-based observations made in 2015 or 2016 and the best matched fire behavior fuel model (FBFM; dashed line and triangles) from Scott and Burgan (2005)

Assuming that decreases in foliar moisture content with time since fire also apply to other forest types that experience stand-replacing fires, values adjusted for stand age may more accurately predict transition of a surface fire to a crown fire. In addition, use of $100 \%$ for foliar moisture values, as recommended when other information is not available (e.g., Finney 1998), may lead to overestimations in critical fireline intensity for stand ages that contain values lower than $100 \%$, such as we observed in the 40- and 107-year-old stands. A somewhat surprising result of our study was that shrub foliar moisture content did not follow a similar pattern to tree foliar moisture across sites. The reason for the absence of a time-since-fire pattern in shrub foliar moisture content is unknown but may reflect differences in the species present across sites, different physiological processes among tree and shrub species, or access to different water sources in the soil horizon.
In accordance with previous findings, foliar moisture content was lower in old foliage than in new foliage (Van Wagner 1967; Gary 1971; Chrosciewicz 1986; Agee et al. 2002; Jolly et al. 2014). Young foliage typically contains higher moisture content due to lower non-structural carbohydrates and crude fats compared to older foliage (Gary 1971; Jolly et al. 2014). However, it is important to note that younger stands have a higher proportion of younger foliage than older stands and, thus, would have higher foliar moisture content at the whole-tree scale, a distinction that is not typically accounted for when modeling fire behavior, as has been noted by others (Agee et al. 2002; Jolly et al. 2014).

\section{Fire behavior and mortality patterns}

Fire behavior modeling for the stands observed along the Baker cypress time-since-fire chronosequence indicated that these conditions could sustain combustion that is sufficient to kill Baker cypress and that these stands do not 
appear to be fuel or moisture limited. In other words, there was sufficient fuel to carry fire and the elevated foliar moisture content of Baker cypress on younger sites did not affect potential fire spread. It is important to point out that our results are strictly based on modeled fire behavior, which can be quite sensitive to the fuel models selected to represent fuel conditions across the chronosequence. Our results indicated that fire behavior would take a U-shaped distribution as stand age increased, which is consistent with the observed fine woody loading and fuelbed depth patterns. However, there is a possibility that the density of the young cypress trees in the 40-year-old stand may be better represented as a shrub fuel model due to their short stature. We opted to characterize this stand as a TU1 fuel model because of the large distances between trees (Fig. 1d). Additionally, the surface fire behavior model employed assumed a uniform distribution of fuels (Rothermel 1972) and did not account for the observed patchiness of fuels in some stands. For instance, in the 3-year-old stand, we did not observe litter loading on $62.5 \%$ of the transects, suggesting that, if burning is sustained, it may be quite patchy, possibly allowing some Baker cypress to survive. Based on our modeled fire behavior and stand information, post-fire mortality in Baker cypress was $100 \%$ for the three oldest sites and would likely extend to younger sites if modeling was possible for these size classes. The persistently thin bark of Baker cypress is unlikely to provide sufficient protection from even modest fire behavior.

Time since fire had a strong influence on modeled surface fire behavior in Baker cypress forests. These results were consistent with another study of fuel succession following stand-replacing fire in western hemlock (Tsuga heterophylla [Raf.] Sarg.)-Douglas-fir forests: Agee and Huff (1987) found increased surface fire behavior in young stands, a subsequent reduction in fire behavior in intermediate-aged stands, and a gradual increase in the oldest stands of the post-fire chronosequence. While the specific timing of fine fuel and surface fire increases differed compared to our study, both forest types followed a more or less U-shaped distribution in fine woody fuels, and fire behavior that spanned the range of stand developmental stages.

\section{Conclusions}

The onset of rapid climate change, changing fire regimes (Westerling 2016; Parks et al. 2017), and intensified droughts (Enright et al. 2015) have prompted concerns for the persistence of obligate-seeding species (Turner 2010; Buma et al. 2013). In the case of Baker cypress, populations that experience a short-interval fire before a sufficient production of cones would be substantially reduced or eliminated. While our modeling indicates that fuel conditions are suitable for these types of events to occur, it does not indicate the likelihood of fire occurring (i.e., ignition). Recent projections of annual fire probability for 2026 to 2050, based on a model of fire occurrence developed for California (Mann et al. 2016), suggest that the probability of fire occurring for most of the Baker cypress range is < $1 \%$ per year (CalFire 2019). Thus, the probability of a fire burning a second time before the stand reaches maturity is likely extremely low, and we are unaware of any population that has experienced such a short-interval fire in Baker cypress; however, recurrent fire within seven years that resulted in no regeneration was recently observed for Tecate cypress (Hesperocyparis forbesii [Jeps.] Bartel) in southern California (Brennan and Keeley 2019).

The possibility of immaturity risk occurring in Baker cypress is also dependent on the time at which a sufficient number of cones are produced to replace the stand. We did not observe cone production within stands in our study sites younger than the 26-year-old stand, which had an average of 120 cones per tree (Table 1). However, it is important to note that trees at this site were planted and likely represent a higher level of cone production than would occur in most post-fire regenerated stands at this stand age. There were no cones on the sampled trees at the 10-year-old site, but we did observe that some (very few) individual trees bore a single cone at this age. Assuming that there are only about four viable seeds per cone (McNamara 2018) and an expected seedling survival rate of about 10\% (Greene and Johnson 1998), young stands like this that have few individuals bearing cones may be incapable of replacing the population after fire. Likewise, Merriam and Rentz (2010) observed a 16-year-old stand that did not yet bear cones. Consistent cone production in Baker cypress probably does not occur for at least two decades and possibly longer for less productive sites. Estimates for a related species, the Tecate cypress of southern California, indicated that a fire return interval shorter than $40 \mathrm{yr}$ would result in a substantial population reduction (Rodríguez-Buriticá and Suding 2013).

Our study demonstrates that fuel conditions in young Baker cypress stands are conducive to burning and can result in substantial fire behavior and post-fire mortality, but likely represent relatively low probability events. Still, given that Baker cypress is quite rare, the loss of any population is problematic. As such, we recommend the exclusion of fire in stands younger than $20 \mathrm{yr}$ to prevent the potential loss of a population due to immaturity risk. Treating adjacent areas around Baker cypress populations may also help facilitate the ability to suppress fire in younger stands. In stands older than $20 \mathrm{yr}$, fuel conditions and sufficient cone production would promote stand replacement following fire and eliminate the competitors that would eventually overtop Baker cypress.

\section{Acknowledgements}

The Baker Cypress Restoration Stewardship Grant administered by the US Bureau of Land Management, Redding Field Office, provided funding support for this project. A California State University Agricultural Research 
Institute Grant (19-06-100) provided additional funding support. L. Brodhead provided planning support to allow for research at the Upper Burney Creek Baker Cypress Research Natural Area. K. Merriam shared her knowledge throughout this project and coordinated a helpful workshop to discuss broader management concerns regarding Baker cypress. The United States Forest Service granted a permit for data collection at the Mud Lake Research Natural Area. We thank A. Williams, B. Henry, C. Harris, J. Avitia, J. Dorman, L. Rios, and M. Wright for field and lab assistance on this project. We also thank four anonymous reviewers and the associate editor for providing helpful feedback on an earlier version of the paper.

\section{Authors' contributions}

JK and DG conceived of the project idea and procured funding to support the work. BM and JK analyzed the data, interpreted the findings, and wrote the major portions of the manuscript. All authors read and reviewed earlier drafts of the manuscript and approved the final version.

\section{Funding}

This project was funded by the Baker Cypress Restoration Stewardship Grant administered by the US Bureau of Land Management and a grant from the California State University Agricultural Research Institute Grant (19-06-100).

\section{Availability of data and materials}

The datasets used or analyzed during the current study are available from the corresponding author on reasonable request.

\section{Ethics approval and consent to participate}

Not applicable.

\section{Consent for publication}

Not applicable.

\section{Competing interests}

The authors declare that they have no competing interests.

Received: 26 February 2019 Accepted: 25 October 2019

\section{Published online: 26 November 2019}

\section{References}

Abatzoglou, J.T. 2013. Development of gridded surface meteorological data for ecological applications and modelling. International Journal of Climatology 33: 121-131. https://doi.org/10.1002/joc.3413.

Abatzoglou, J.T., and T.J. Brown. 2012. A comparison of statistical downscaling methods suited for wildfire applications. International Journal of Climatology 32: 772-780. https://doi.org/10.1002/joc.2312.

Agee, J.K., and M.H. Huff. 1987. Fuel succession in a western hemlock/Douglas-fir forest. Canadian Journal of Forest Research 17: 697-704. https://doi.org/10. 1139/x87-112.

Agee, J.K., C.S. Wright, N. Williamson, and M.H. Huff. 2002. Foliar moisture content of Pacific Northwest vegetation and its relation to wildland fire behavior. Forest Ecology and Management 167: 57-66. https://doi.org/10.1016/S03781127(01)00690-9.

Andrews, P.L. 2012. Modeling wind adjustment factor and midflame wind speed for Rothermel's surface fire spread model. USDA Forest Service General Technical Report RMRS-GTR-266. Fort Collins: USDA Forest Service, Rocky Mountain Research Station. https://doi.org/10.2737/RMRS-GTR-266

Andrews, P.L. 2014. Current status and future needs of the BehavePlus Fire Modeling System. International Journal of Wildland Fire 23: 21-33. https://doi. org/10.1071/WF12167.

Apple, M., K. Tiekotter, M. Snow, J. Young, A. Soeldner, D. Phillips, D. Tingey, and B.J. Bond. 2002. Needle anatomy changes with increasing tree age in Douglas-fir. Tree Physiology 22: 129-136. https://doi.org/10.1093/treephys/22.2-3.129.

Bessie, W.C., and E.A. Johnson. 1995. The relative importance of fuels and weather on fire behavior in subalpine forests. Ecology 76: 747-762. https:// doi.org/10.2307/1939341.

Bower, A.D., and V. Hipkins. 2017. Genetic diversity and population structure in the rare, endemic Baker cypress (Hesperocyparis bakeri). Madroño 64: 71-82. https://doi.org/10.3120/0024-9637-64.2.71.

Bowman, D.M.J.S., B.P. Murphy, D.L.J. Neyland, G.J. Williamson, and L.D. Prior. 2014. Abrupt fire regime change may cause landscape-wide loss of mature obligate seeder forests. Global Change Biology 20 (3): 1008-1015. https://doi. org/10.1111/gcb.12433.

Bradshaw, L., and E. McCormick. 2000. FireFamily Plus user's guide, version 2.0. USDA Forest Service General Technical Report RMRS-GTR-67. Ogden: USDA Forest Service, Rocky Mountain Research Station. https://doi.org/10.2737/RMRS-GTR-67.

Brennan, T.J., and J.E. Keeley. 2019. Postfire population dynamics of a firedependent cypress. Plant Ecology 220 (6): 605-617. https://doi.org/10.1007/ s11258-019-00939-8.

Brown, J.K. 1974. Handbook for inventorying downed woody material. USDA Forest Service General Technical Report INT-GTR-16. Ogden: USDA Forest Service, Intermountain Forest and Range Experiment Station.

Brown, J.K., and T.E. See. 1981. Downed dead woody fuel and biomass in the northern Rocky Mountains. USDA Forest Service General Technical Report INT-GTR-117. Ogden: USDA Forest Service, Intermountain Forest and Range Experiment Station.

Buma, B., C.D. Brown, D.C. Donato, J.B. Fontaine, and J.F. Johnstone. 2013. The impacts of changing disturbance regimes on serotinous plant populations and communities. BioScience 63: 866-876. https://doi.org/10.1525/bio.2013.63.11.5.

Burnham, K.P., and D.R. Anderson. 1998. Model selection and inference: a practical information-theoretic approach. New York: Springer. https://doi.org/10.1007/ 978-1-4757-2917-7_3.

CalFire [California Department of Forestry \& Fire Protection]. 2018. California Department of Forestry and Fire Protection, Fire and Resource Assessment Program. 2017 fire perimeter data. https://frap.fire.ca.gov/mapping/gis-data/. Accessed 16 Oct. 2019.

CalFire [California Department of Forestry \& Fire Protection]. 2019. California Department of Forestry and Fire Protection, Fire and Resource Assessment Program. Annual fire probability map. https://frap.fire.ca.gov/frap-projects/ fire-probability-and-carbon-accounting/. Accessed 16 Oct. 2019.

Carlton, D. 2005. Fire Management Analyst Plus. Sandy: Fire Program Solutions.

Catchpole, E., and W. Catchpole. 1991. Modelling moisture damping for fire spread in a mixture of live and dead fuels. International Journal of Wildland Fire 1 (2): 101-106. https://doi.org/10.1071/WF9910101.

Chrosciewicz, Z. 1986. Foliar moisture content variations in four coniferous tree species of central Alberta. Canadian Journal of Forest Research 16: 157-162. https://doi.org/10.1139/x86-029.

Cohen, J.D., and J.E. Deeming. 1985. The national fire-danger rating system: basic equations. USDA Forest Service General Technical Report PSW-GTR-82. Berkeley: USDA Forest Service, Pacific Southwest Forest and Range Experiment Station. https://doi.org/10.2737/PSW-GTR-82.

Davies, G.M., C.J. Legg, A.A. Smith, and A.J. MacDonald. 2009. Rate of spread of fires in Calluna vulgaris-dominated moorlands. Journal of Applied Ecology 46: 1054-1063. https://doi.org/10.1111/j.1365-2664.2009.01681.x.

Davis, B., J. van Wagtendonk, J. Beck, and K. van Wagtendonk. 2009. Modeling fuel succession. Fire Management Today 69 (2): 18-21 https://www.fs.usda. gov/treesearch/pubs/35440.

de Gouvenain, R.C., and A.M. Ansary. 2006. Association between fire return interval and population dynamics in four California populations of Tecate cypress (Cupressus forbesii). The Southwestern Naturalist 51: 447-454. https:// doi.org/10.1894/0038-4909(2006)51[447:ABFRIA]2.0.CO;2.

Dunn, C.J, and J.D. Bailey. 2015. Modeling the direct effects of salvage logging on long-term temporal fuel dynamics in dry-mixed conifer forests. Forest Ecology and Management 341: 93-109. https://doi.org/10.1016/j.foreco.2015.01.002.

Enright, N.J., J.B. Fontaine, D.M.J.S. Bowman, R.A. Bradstock, and R.J. Williams. 2015. Interval squeeze: altered fire regimes and demographic responses interact to threaten woody species persistence as climate changes. Frontiers in Ecology and the Environment 13: 265-272. https://doi.org/10.1890/140231.

Enright, N.J., B.B. Lamont, and R. Marsula. 1996. Canopy seed bank dynamics and optimum fire regime for the highly serotinous shrub, Banksia hookeriana. Journal of Ecology 84 (1): 9-17. https://doi.org/10.2307/2261695.

Fahnestock, G.R. 1976. Fire, fuels and flora as factors in wilderness management: the Pasyten case. In Proceedings of the $15^{\text {th }}$ annual Tall Timbers Fire Ecology Conference, 1974 October 16-17, Portland, Oregon, 33-70. Tallahassee: Tall Timbers Research Station.

Fairman, T.A., L.T. Bennett, S. Tupper, and C.R. Nitschke. 2017. Frequent wildfires erode tree persistence and alter stand structure and initial composition of a fire-tolerant sub-alpine forest. Journal of Vegetation Science 28: 1151-1165. https://doi.org/10.1111/jvs.12575.

Farjon, A. 2013. Cupressus bakeri. The IUCN Red List of Threatened Species 2014: e.T34047A2841226. https://doi.org/10.2305/IUCN.UK.2013-1.RLTS. T34047A2841226.en. Accessed 16 Oct. 2019. 
Finney, M.A. 1998. FARSITE: Fire Area Simulator-model development and evaluation. USDA Forest Service Research Paper RMRS-RP-4, revised 2004. Fort Collins: USDA Forest Service, Rocky Mountain Research Station. https://doi.org/10.2737/RMRS-RP-4.

Gary, H.L. 1971. Seasonal and diurnal changes in moisture contents and water deficits of Engelmann spruce needles. Botanical Gazette 132: 327-332. https://doi.org/10.1086/336598.

Greene, D.F., and E.A. Johnson. 1998. Seed mass and juvenile survivorship of trees in clearings and shelterwoods. Canadian Journal of Forest Research 28: 13071316. https://doi.org/10.1139/x98-106.

Jolly, W.M., A.M. Hadlow, and K. Huguet. 2014. De-coupling seasonal changes in water content and dry matter to predict live conifer foliar moisture content. International Journal of Wildland Fire 23: 480-489. https://doi.org/10.1071/WF13127.

Jolly, W.M., and D.M. Johnson. 2018. Pyro-ecophysiology: shifting the paradigm of live wildland fuel research. Fire 1 (1): 8. https://doi.org/10.1071/WF13127.

Kashian, D.M., W.H. Romme, D.B. Tinker, M.G. Turner, and M.G. Ryan. 2013. Postfire changes in forest carbon storage over a 300-year chronosequence of Pinus contorta-dominated forests. Ecological Monographs 83: 49-66. https://doi.org/10.1890/11-1454.1.

Keeley, J.E., C.J. Fotheringham, and M. Morais. 1999a. Reexamining fire suppression impacts on brushland fire regimes. Science 284: 1829-1832 https://doi.org/10.1126/science.284.5421.1829.

Keeley, J.E., G. Ne'eman, and C.J. Fotheringham. 1999b. Immaturity risk in a firedependent pine. Journal of Mediterranean Ecology 1: 41-48.

Keyes, C.R. 2006. Role of foliar moisture content in the silvicultural management of forest fuels. Western Journal of Applied Forestry 21: 228-231. https://doi. org/10.1093/wjaf/21.4.228.

Lotan, J.E., J.K. Brown, and L.F. Neuenschwander. 1985. Role of fire in lodgepole pine forests. In Lodgepole pine the species and its management symposium proceedings, ed. D.M. Baumgartner, R.G. Krebill, J.T. Arnott, and G.F. Weetman, 133-152. Pullman: Washington State University.

Lutes, D.C. 2019. First Order Fire Effects Model: FOFEM 6.5, user's guide. Missoula: USDA Forest Service, Rocky Mountain Research Station.

Mann, M.L., E. Batllori, M.A. Moritz, E.K. Waller, P. Berck, A.L. Flint, L.E. Flint, and E. Dolfi. 2016. Incorporating anthropogenic influences into fire probability models: effects of human activity and climate change on fire activity in California. PLoS ONE 11 (4): e0153589. https://doi.org/10.1371/journal.pone.0153589.

McNamara, B.A. 2018. Post-fire regeneration and fuel succession pattern in Hesperocyparis bakeri forests, Thesis. Arcata: Humboldt State University.

Merriam, K., and E. Rentz. 2010. Restoring fire to endemic cypress populations in northern California. Joint Fire Science Program Final Report. JFSP project ID number 06-2-117. Boise: Joint Fire Science Program.

Milich, K.L., J.D. Stuart, J.M. Varner III, and K.E. Merriam. 2012. Seed viability and firerelated temperature treatments in serotinous California native Hesperocyparis species. Fire Ecology 8 (2): 107-124. https://doi.org/10.4996/fireecology.0802107.

Miller, J.D., H.D. Safford, M. Crimmins, and A.E. Thode. 2009. Quantitative evidence for increasing forest fire severity in the Sierra Nevada and southern Cascade Mountains, California and Nevada, USA. Ecosystems 12: 16-32. https://doi.org/ 10.1007/s10021-008-9201-9.

Moritz, M.A., J.E. Keeley, E.A. Johnson, and A.A. Schaffner. 2005. Testing a basic assumption of shrubland fire management: how important is fuel age? Frontiers in Ecology and the Environment 2 (2): 67-72. https://doi.org/10.1890/ 1540-9295(2004)002[0067:TABAOS]2.0.CO;2.

Parks, S.A., L.M. Holsinger, C.Miller, and C.R. Nelson. 2015. Wildland fire as a self-regulating mechanism: the role of previous burns and weather in limiting fire progression. Ecological Applications 25: 1478-1492. https://doi.org/10.1890/14-1430.1

Parks, S.A., L.M. Holsinger, C. Miller, and M.-A. Parisien. 2017. Analog-based fire regime and vegetation shifts in mountainous regions of the western US. Ecography 41: 910-921. https://doi.org/10.1111/ecog.03378.

R Development Core Team. 2018. R: a language and environment for statistical computing. Vienna: R Foundation for Statistical Computing.

Reineke, L.H. 1933. Perfecting a stand-density index for even-aged forests. Journal of Agricultural Research 46: 627-638.

Richardson, A.D., G.P. Berlyn, P.M.S. Ashton, R. Thadani, and I.R. Cameron. 2000. Foliar plasticity of hybrid spruce in relation to crown position and stand age. Canadian Journal of Botany 78 (3): 305-317. https://doi.org/10.1139/b00-005.

Rodríguez-Buriticá, S., and K. Suding. 2013. Interactive effects of temporal and spatial fire characteristics on the population dynamics of a fire-dependent cypress species. Journal of Applied Ecology 50: 929-938. https://doi.org/10. 1111/1365-2664.12109.

Romme, W.H. 1982. Fire and landscape diversity in subalpine forests of Yellowstone National Park. Ecological Monographs 52: 199-221. https://doi. org/10.2307/1942611.
Rothermel, R.C. 1972. A mathematical model for predicting fire spread in wildland fuels. USDA Forest Service Research Paper INT-RP-115. Ogden: USDA Forest Service, Intermountain Forest and Range Experiment Station.

Schimmel, J., and A. Granström. 1997. Fuel succession and fire behavior in the Swedish boreal forest. Canadian Journal of Forest Research 27: 1207-1216. https://doi.org/10.1139/x97-072.

Scott, J.H. 2006. Comparison of crown fire modeling systems used in three fire management applications. Fort Collins: USDA Forest Service, Rocky Mountain Research Station. https://doi.org/10.2737/RMRS-RP-58.

Scott, J.H., and R.E. Burgan. 2005. Standard fire behavior fuel models: a comprehensive set for use with Rothermel's surface fire spread model. USDA Forest Service General Technical Report RMRS-GTR-153. Fort Collins: USDA Forest Service, Rocky Mountain Research Station. https://doi.org/10.2737/ RMRS-GTR-153.

Scott, J.H., and E.D. Reinhardt. 2001. Assessing crown fire potential by linking models of surface and crown fire behavior. USDA Forest Service Research Paper RMRS-RP-29. Fort Collins: USDA Forest Service, Rocky Mountain Research Station. https://doi.org/10.2737/RMRS-RP-29.

Skinner, C.N., and A.H. Taylor. 2018. Chapter twelve. Southern Cascades Bioregion. In Fire in California's ecosystems, second edition, ed. Jan van Wagtendonk, 195-218. Berkeley: University of California Press. https://doi.org/10.1525/ 9780520961913-015.

Turner, M.G. 2010. Disturbance and landscape dynamics in a changing world. Ecology 91: 2833-2849. https://doi.org/10.1890/10-0097.1.

Van Wagner, C.E. 1967. Season variation in moisture content of eastern Canadian tree foliage and the possible effect on crown fires. Ottawa: Canada Department of Forestry and Rural Development.

Van Wagner, C.E. 1977. Conditions for the start and spread of crown fire. Canadian Journal of Forest Research 7: 23-34. https://doi.org/10.1139/x77-004.

van Wagtendonk, J.W., J.M. Benedict, and W.M. Sydoriak. 1998. Fuelbed characteristics of Sierra Nevada conifers. Western Journal of Applied Forestry 13: 73-84. https://doi.org/10.1093/wjaf/13.3.73.

Walker, L.R., D.A. Wardle, R.D. Bardgett, and B.D. Clarkson. 2010. The use of chronosequences in studies of ecological succession and soil development: chronosequences, succession and soil development. Journal of Ecology 98: 725-736. https://doi.org/10.1111/j.1365-2745.2010.01664.x.

Westerling, A.L. 2016. Increasing western US forest wildfire activity: sensitivity to changes in the timing of spring. Philosophical Transactions of the Royal Society B 371: 20150178. https://doi.org/10.1098/rstb.2015.0178.

Woodall, C.W., P.D. Miles, and J.S. Vissage. 2005. Determining maximum stand density index in mixed species stands for strategic-scale stocking assessments. Forest Ecology and Management 216: 367-377. https://doi.org/ 10.1016/j.foreco.2005.05.050.

Zahn, S., and C. Henson. 2011. A synthesis of fuel moisture collection methods and equipment - a desk guide. San Dimas: USDA Forest Service, National Technology and Development Center.

Zedler, P.H. 1977. Life history attributes of plants and the fire cycle: a case study in chaparral dominated by Cupressus forbesii. In Proceedings of the symposium on the environmental consequences of fire and fuel management in Mediterranean ecosystems. USDA Forest Service General Technical Report WO-3, Technical coordination by H.A. Mooney and C.E. Conrad, 451-458. Washington, D.C.: US Department of Agriculture, Forest Service.

Zedler, P.H., C.R. Gautier, and G.S. McMaster. 1983. Vegetation change in response to extreme events: the effect of a short interval between fires in California chaparral and coastal scrub. Ecology 64: 809-818. https://doi.org/10.2307/1937204.

\section{Publisher's Note}

Springer Nature remains neutral with regard to jurisdictional claims in published maps and institutional affiliations. 